\title{
Patients with chronic myeloid leukemia treated with imatinib who showed the appearance of clonal cytogenetic abnormalities in Philadelphia chromosome-negative cells
}

Blood Cancer Journal (2011) 1, e45; doi:10.1038/bcj.2011.45; published online 11 November 2011

Chronic myeloid leukemia (CML) is a myeloproliferative disorder, characterized by the presence of the Philadelphia $(\mathrm{Ph})$ chromosome, a consequence of a reciprocal translocation between chromosomes 9 and 22, resulting in the fusion of the genes $B C R$ and $A B L$. The $B C R-A B L$ fusion gene encodes a constitutively active leukemogenic protein tyrosine kinase. BCR-ABL kinase activity is inhibited by the selective activity of imatinib, a target agent that has demonstrated remarkable efficacy and tolerability. ${ }^{1}$ It has been shown that imatinib blocks cell proliferation and induces apoptosis in BCR-ABL-expressing hematopoietic cells. Imatinib has been used as a first line therapy for $\mathrm{CML}$ patients. ${ }^{2}$ Different patterns of response to imatinib treatment have been recognized, ranging from bestcase scenarios of rapid and unwavering response to difficult situations of intolerance and resistance, either primary or secondary. ${ }^{3}$ In general, most patients under imatinib achieve a major or complete cytogenetic response (CCyR), with restoration of a Ph-negative hematopoiesis. However, recently, some studies showed the appearance of clonal chromosomal abnormalities in patients with Ph-negative cells under imatinib treatment. ${ }^{4-7}$ In this study, we describe four cases of $\mathrm{CML}$ patients treated with imatinib. These patients showed cytogenetic response with the disappearance of Ph-positive cells, but they acquired other clonal chromosomal abnormalities. In three cases, we had an extra chromosome $\mathrm{Y}$ and, in one case, the trisomy of 8. To our knowledge, this is the first study that discusses the acquisition of an extra chromosome $Y$ in patients treated with imatinib who had cytogenetic response.

Between 2000 and 2010 we studied, cytogenetically and clinically, 100 patients with $\mathrm{CML}$, who were treated with imatinib at National Cancer Institute, Rio de Janeiro, Brazil. At the beginning of the therapy with imatinib, 66 patients were in chronic phase $(\mathrm{CP}), 24$ patients in accelerated phase (AP) and 10 in blast crisis (BC). These patients were previously treated with hydroxyurea and interferon- $\alpha$. There were 57 males and 43 females. The mean age of our patients were 48 years old (range from 14 to 75 years old). These patients were monitored by cytogenetic and molecular analyses during the treatment with imatinib. This study was reviewed and approved by the Ethical Committee from National Cancer Institute and it was in accordance with the Helsinki Declaration of 1975.

Karyotypes of bone marrow cells were obtained from cultures in RPMI 1640 with $20 \%$ fetal calf serum at $37^{\circ} \mathrm{C}$ for $24 \mathrm{~h}$. Cell cultures were pulsed with colcemid. Cells were subsequently harvested by standard procedures and fixed in methanol-acetic acid. The chromosomes were analyzed by G-banding. The cytogenetic response was defined by the percentage of cells in metaphase, which was positive for the Ph chromosome in the bone marrow. ${ }^{1}$ Fluorescence in situ hybridization (FISH) analysis was applied to fixed cell suspensions. We used the probes: LSI BCR/ABL1 dual-color, single-fusion probe; LSI c-myc (8q24.12-q24.13) (Vysis, Abbott Molecular, Des Plaines, IL, USA) and LPE OYqR (Cytocell, Cambridge, UK). FISH was performed according to the recommendations of the manufactures. The molecular analysis was done to investigate the presence of the fusion transcripts (b3a2 or b2a2), using reverse transcription (RT)-PCR and nested PCR in diagnosis. During the treatment, it was also performed the real-time RT-PCR.

We did statistical analysis to show that the presence of $\mathrm{Ph}$ chromosome, as sole chromosomal abnormality, is significantly higher in patients at $\mathrm{CP}$ than in patients at AP and BC. We also proved statistically that the influence of $\mathrm{Ph}$ chromosome as sole chromosomal abnormality is higher in the cytogenetic response of patients treated with imatinib, compared with the influence of $\mathrm{Ph}$ chromosome with additional abnormalities. $P<0.01$ was considered significant in all analyses.

One hundred patients with CML were studied cytogenetically and clinically during the treatment with imatinib. Among these patients, 74 had the $\mathrm{Ph}$ chromosome as sole chromosomal abnormality (74\%) and 26 had $\mathrm{Ph}$ chromosome and additional chromosomal abnormalities (26\%) before beginning the treatment. Patients only with $\mathrm{Ph}$ chromosome before the treatment were more frequently in $\mathrm{CP}$ than in $\mathrm{AP}$ and $\mathrm{BC}$ (81\% versus $19 \%, P<0.001)$. Also, the patients with only the Ph-positive cells had a significant higher rate of major cytogenetic response than the patients with $\mathrm{Ph}$ and additional chromosomal abnormalities $(90 \%$ versus $10 \%, P<0.001)$. Based on clinical results from randomized trials, imatinib is approved for all phases of $\mathrm{CML}$, but best results of this treatment is observed in CML patients at the initial phase of the disease, as observed in our study and others. ${ }^{8}$

From the total of 100 patients studied, we observed the appearance of clonal chromosomal alterations during the imatinib treatment in four cases. The chromosome $\mathrm{Ph}$ was the only karyotypic abnormality. The molecular analysis showed the presence of the fusion transcripts: b2a2 in patients 1,2 and 3 ; the $\mathrm{b} 3 \mathrm{a} 2$ in patient 4 . The patients were in $\mathrm{CP}$ and they received $400 \mathrm{mg}$ per day of imatinib after interferon- $\alpha$ resistance/intolerance. After the patients had achieved a CCyR, with Ph-negative cells, which was observed by G-banding and FISH analysis, it was detected the presence of clonal cytogenetic abnormalities. Three patients showed the gain of chromosome $Y$ (Figure 1) and one patient acquired trisomy 8 . The patients achieved hematologic, cytogenetic and molecular responses. They showed no clinical symptoms of CML and the imatinib treatment was continued. The mean survival of these four patients was 60 months, since the imatinib treatment had been started. The clinical, cytogenetic and molecular characteristics of the four patients are shown in Table 1.

A cytogenetic phenomenon that has showed considerable interest in the present era of imatinib treatment is the appearance of clonal cytogenetic alterations in Ph-negative cells, which frequency varies greatly, ranging from 2 to $15 \%{ }^{4}$ In our study, this frequency was $4 \%$. The mean time of 

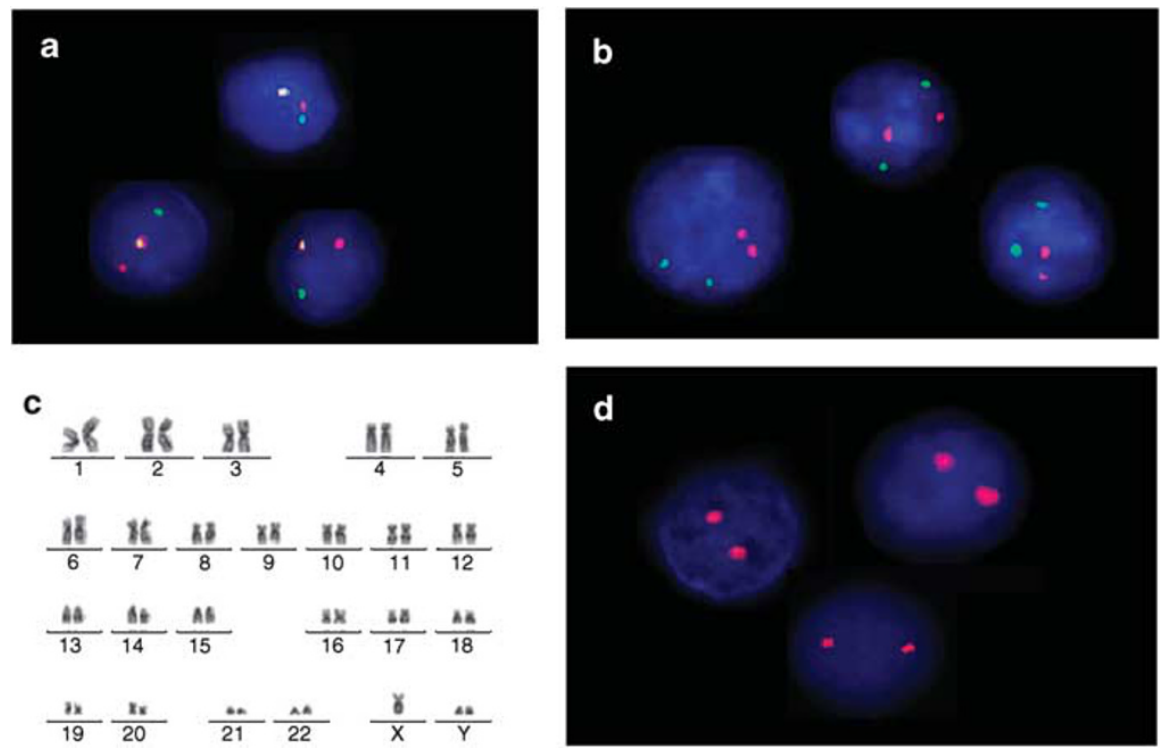

Figure 1 (a) Interphase-FISH (I-FISH) showing Ph-positive cells before imatinib treatment. (b) I-FISH showing Ph-negative cells under imatinib therapy. (c) G-banding showing the karyotype of bone marrow cell: 47,XY, +Y. (d) I-FISH using the probe LPE 0Yq/R showing two signals for Y chromosome.

Table 1 Clinical, cytogenetic and molecular characteristics of the four patients with clonal chromosomal abnormalities in Ph-negative cells during imatinib therapy

\begin{tabular}{|c|c|c|c|c|c|c|c|c|c|c|}
\hline \multicolumn{7}{|c|}{ Diagnosis } & \multicolumn{4}{|c|}{ Imatinib treatment } \\
\hline \multirow[t]{2}{*}{ Patient } & \multirow{2}{*}{$\begin{array}{c}\text { Sex/age } \\
\text { (years) }\end{array}$} & \multicolumn{3}{|c|}{ Peripheral blood counts } & \multirow{2}{*}{$\begin{array}{l}\text { Cytogenetic } \\
\text { analysis } \\
\text { G-banding }\end{array}$} & \multirow{2}{*}{$\begin{array}{c}\text { Molecular } \\
\text { analysis } \\
\text { Nested PCR }\end{array}$} & \multirow{2}{*}{$\begin{array}{c}\text { CCyR } \\
\text { (months) }\end{array}$} & \multirow{2}{*}{$\begin{array}{c}\text { Cytogenetic } \\
\text { alterations in } \\
\text { Ph-negative cells }\end{array}$} & \multirow{2}{*}{$\begin{array}{l}\text { Time of } \\
\text { detection } \\
\text { (months) }\end{array}$} & \multirow{2}{*}{$\begin{array}{c}\text { Status } \\
\text { (follow-up, } \\
\text { in months) }\end{array}$} \\
\hline & & $\begin{array}{l}H b \\
(g / d l)\end{array}$ & $\begin{array}{l}\text { Leukocytes } \\
\times 10^{3} / \mathrm{mm}^{3}\end{array}$ & $\begin{array}{l}\text { Platelets } \\
\times 10^{3} / \mathrm{mm}^{3}\end{array}$ & & & & & & \\
\hline 1 & M/36 & 7.97 & 106 & 409 & $46, X Y, t(9 ; 22)(q 34 ; q 11)[25]$ & b2a2 & 6 & $47, X Y,+Y[5] / 46, X Y[25]$ & 72 & Alive (84) \\
\hline 2 & M/35 & 10.2 & 89.9 & 676 & $46, X Y, t(9 ; 22)(q 34 ; q 11)[20]$ & b2a2 & 12 & $47, X Y,+Y[6] / 46, X Y[19]$ & 44 & Alive (72) \\
\hline 3 & $\mathrm{M} / 57$ & 13.4 & 42.7 & 531 & $46, X Y, t(9 ; 22)(q 34 ; q 11)[51]$ & b2a2 & 12 & $47, X Y,+Y[3] / 46, X Y[17]$ & 48 & Alive (60) \\
\hline 4 & $\mathrm{~F} / 47$ & 9.0 & 83.8 & 348 & $46, X X, t(9 ; 22)(q 34 ; q 11)[20]$ & b3a2 & 15 & $47, X X,+8[10] / 46, X X[10]$ & 21 & Alive (24) \\
\hline
\end{tabular}

Abbreviations: CCyR, complete cytogenetic response; F, female; Hb, hemoglobin; M, male.

appearance of clonal cytogenetic abnormalities was 46 months after imatinib therapy started. A review of the literature showed that this period may vary from 3 to 47 months. ${ }^{4}$ The most common changes observed in Ph-negative cells are: $-7,+8$, -5 and $-Y$. Such changes are also presented in myelodysplastic syndromes (MDS) and acute myeloid leukemia (AML), which has raised concerns about their clinical implication. The frequency of MDS/AML in such patients is in order of 2 $10 \% .{ }^{9-11}$ Analyzing the bone marrow of our four patients, they did not show the morphologic features of MDS/AML. Lin et al. ${ }^{6}$ also showed no association with MDS/AML. Jabbour et al. ${ }^{7}$ suggested that patients with $C M L$ require continued monitoring with cytogenetic analysis, but in the absence of additional clinical complications (for example, trilineage dysplasia) a change in treatment strategy is not necessarily indicated.

In our study, we observed an acquisition of an extra chromosome $Y$ in three cases and in one case the trisomy 8 . The trisomy 8 is well documented in the literature. Nevertheless, an extra chromosome $Y$ is a rare phenomenon in leukemia. It was described by Watanabe et al. ${ }^{12}$ in one case of T-cell acute lymphoblastic leukemia, as a sole chromosome abnormality and the patient achieved complete remission by chemotherapy. Interesting, Deininger et al. ${ }^{4}$ studied 532 patients with CML treated with imatinib. They related that the most frequently involved chromosomes were $\mathrm{Y}$ and 8 in cases with Ph-negative cells in response to imatinib, with a frequency of $37 \%$ and $27 \%$, respectively. ${ }^{4}$ But, Deininger et al. ${ }^{4}$ also detected an extra chromosome $\mathrm{Y}$ in three $\mathrm{CML}$ patients with $\mathrm{Ph}$-negative cells in response to imatinib treatment. Nevertheless, these findings were not yet discussed in the literature, as most cases with the involvement of chromosome $\mathrm{Y}$ are related to loss of this chromosome and not the gain. The loss of the chromosome $Y$ in hematologic neoplasms is frequently associated with a favorable prognosis. ${ }^{4,13}$ Although, Lippert et al. related that the loss of $\mathrm{Y}$ chromosome in Ph-positive cells predicts a poor response of $\mathrm{CML}$ patients to imatinib therapy. ${ }^{14}$ These findings raise the question: Which genes are localized in $\mathrm{Y}$ chromosome that may be associated with imatinib response? Analyzing the genes localized in chromosome $Y$ we can find: SRY (sex determining region Y), TGIF2Ly (TGFB-induced factor homeobox 2-like), PCDH11Y (protocadherin 11), PRKY (protein kinase), TSPY 1 (testis-specific protein), USP9Y (ubiquitinspecific peptidase 9), DDX3Y (DEAD box polypeptide 3), CD24 (CD24 molecule), RBMY1A1 (RNA-binding motif protein). ${ }^{15}$ It may be possible that some of these genes, such as: TGIF2Ly, PRKY, RBMY1A1, may be influencing the 
transductional signal in imatinib response. So, they may be candidates of future studies.

Despite the increased number of reports of Ph-negative clones, the significance and potential causes for Ph-negative clonal cytogenetic abnormalities in hematopoiesis remain unclear. Some studies associated the development of clonal cytogenetic abnormalities by previous treatment like hydroxyurea or IFN- $\alpha$. Nevertheless, some studies have been shown the clonal cytogenetic alterations in larger series of patients receiving only imatinib treatment. ${ }^{7}$ But, in fact, more studies with longer follow-up in larger patient cohorts are necessary to enable researchers to answer the significance of the acquired clonal chromosome abnormalities during imatinib therapy, their correlation into the basic CML pathogenesis and their clinical impact.

\section{Conflict of interest}

The authors declare no conflict of interest.

MM da Rocha ${ }^{1}$, L Otero ${ }^{1}$, TF Padilha ${ }^{2}$, J Dobbin ${ }^{3}$ $\mathrm{C}$ de Souza Fernandez ${ }^{4}, \mathrm{E}$ Abdelhay ${ }^{1}$ and

T de Souza Fernandez ${ }^{1}$

${ }^{1}$ Cytogenetic Laboratory, Bone Marrow Transplantation Centre, National Cancer Institute (INCA),

Rio de Janeiro, RJ, Brazil;

${ }^{2}$ Molecular Biology Laboratory, Bone Marrow Transplantation Centre, National Cancer Institute (INCA)

Rio de Janeiro, RJ, Brazil;

${ }^{3}$ Hematology Service, National Cancer Institute, Rio de Janeiro, RJ, Brazil and

${ }^{4}$ Mathematics and Statistics Institute, Federal Fluminense University (UFF), Niterói, RJ, Brazil E-mail: teresafernandez@inca.gov.br

\section{References}

1 Druker BJ, Talpaz M, Resta DJ, Peng B, Buchdunger E, Ford JM et al. Efficacy and safety of specific inhibitor of BCR-ABL tyrosine kinase in chronic myeloid leukemia. N Engl J Med 2001; 344: 1031-1037.

2 Pavlovsky C, Kantarjian H, Cortes JE. First line therapy for chronic myeloid leukemia: past, present and future. Am J Hematol 2009; 84: 287-293.

3 Kantarjian H, Sawyers C, Hochhaus A, Guilhot F, Schiffer C, Gambacorti-Passerini $\mathrm{C}$ et al. Hematologic and cytogenetic responses to imatinib mesylate in chronic myelogenous leukemia N Engl J Med 2002; 346: 645-652.
4 Deininger MW, Cortes J, Paquette R, Park B, Hochhaus A, Baccarani $\mathrm{M}$ et al. The prognosis for patients with chronic myeloid leukemia who have clonal cytogenetic abnormalities in Philadelphia chromosome-negative cells. Cancer 2007; 110: 1509-1519.

5 Guilbert-Douet N, Morel F, Le Bris M-J, Berthou C, Morice P, Bourquard $\mathrm{P}$ et al. Clonal chromosomal abnormalities in the Philadelphia negative cells of chronic myeloid leukemia patients treated with imatinib. Leukemia 2004; 18: 1140-1142.

6 Lin $\mathrm{Y}$, Bruyère $\mathrm{H}$, Horsman DE, Pantzar T, Barnett MJ, Hogge DE et al. Philadelphia-negative clonal hematopoiesis following imatinib therapy in patinets with chronic myeloid leukemia: a report of nine cases and analysis of predictive factors. Cancer Genet Cytogenet 2006; 170: 16-23.

7 Jabbour E, Kantariian HM, Abruzzo LV, O'Brien S, Garcia-Manero $\mathrm{G}$, Verstovsek $\mathrm{S}$ et al. Chromosomal abnormalities in Philadelphia chromosome negative metaphases appearing during imatinib mesylate therapy in patients with newly diagnosed chronic myeloid leukemia in chronic phase. Blood 2007; 110: 2991-2995.

8 Hochhaus A, Druker B, Sawyers C, Guilhot F, Schiffer CA, Cortes J et al. Favorable long-term follow-up results over 6 years for response, survival and safety with imatinib mesylate therapy in chronic-phase chronic myeloid leukemia after failure of interferonalpha treatment. Blood 2008; 111: 1039-1043.

9 Kovitz C, Kantarjian H, Garcia-Manero G, Abruzzo LV, Cortes J. Myelodysplastic syndromes and acute leukemia developing after imatinib mesylate therapy for chronic myeloid leukemia. Blood 2006; 108: 2811-2813.

10 Navarro JT, Feliu E, Grau J, Espinet B, Colomer D, Ribera JM et al. Monosomy 7 with severe myelodysplasia developing during imatinib treatment of Philadelphia-positive chronic myeloid leukemia: two cases with a different outcome. Am J Hematol 2007; 82: 849-851.

11 Fioretos T, Johansson B. Chronic myeloid leukemia. In: Heim S, Mitelman F (eds). Cancer Cytogenetics, 3rd edn. Wiley-Blackwell, John Wiley \& Sons, Inc: New Jersey, 2009, pp. 179-207.

12 Watanabe A, Yasunori K, Nishihara T, Uchida T, Setsu K, Hikiji K. Extra $\mathrm{Y}$ chromosome in T-cell acute lymphoblastic leukemia. Cancer Genet Cytogenet 1996; 89: 85-87.

13 Wiktor A, Rybicki BA, Piao ZS, Shurafa M, Barthel B, Maeda K et al. Clinical significance of $\mathrm{Y}$ chromosome loss in hematologic disease. Genes Chromosomes Cancer 2000; 27: 11-16.

14 Lippert E, Etienne G, Mozziconacci MJ, Laibe S, Gervais C, Girault S et al. Loss of the $\mathrm{Y}$ chromosome in Philadelphia-positive cells predicts a poor response of chronic myeloid leukemia patients to imatinib mesylate therapy. Haematologica 2010; 95: 1604-1607.

15 Atlas of Genetics and Cytogenetics in Oncology and Haematology. http://atlasgeneticsoncology.org/Indexbychrom/idxg_Y.html.

(c) This work is licensed under the Creative Commons Attribution-NonCommercial-No Derivative Works 3.0 Unported License. To view a copy of this license, visit http:// creativecommons.org/licenses/by-nc-nd/3.0/ 